\title{
EVALUATION OF THE CYTOGENETIC STATUS OF HUMAN LYMPHOCYTES AFTER EXPOSURE TO A HIGH CONCENTRATION OF BEE VENOM IN VITRO
}

\author{
Verica GARAJ-VRHOVAC and Goran GAJSKI \\ Institute for Medical Research and Occupational Health, Mutagenesis Unit, Zagreb, Croatia \\ Received in July 2008 \\ Accepted in September 2008
}

\begin{abstract}
Several studies have reported radioprotective, antimutagenic, anti-inflammatory, antinociceptive, and anticancer effects of bee venom both in the cell and the whole organism. The aim of this study was to assess the effects of a single high dose of $100 \mu \mathrm{g} \mathrm{mL}^{-1}$ of whole bee venom in human lymphocytes in vitro over a variety of time spans (from $10 \mathrm{~min}$ to $24 \mathrm{~h}$ ). After the treatment, we used the comet assay and micronucleus test to see the effect of bee venom on the cell. The comet assay confirmed that the venom damaged the DNA molecule. Tail length, tail intensity, tail moment showed a significant increase $(\mathrm{P}<0.05)$. The percentage of long-tailed nuclei (LTN) with the tail length exceeding the $95^{\text {th }}$ percentile also increased in a time-dependent manner. The micronucleus parameters (number of micronuclei, nucleoplasmic bridges, and nuclear buds) also showed a significant time-dependent increase $(\mathrm{P}<0.05)$. This research indicates that high concentrations of bee venom can lead to cellular instability. Further research is needed to understand the mechanism of action of bee venom and its components in human cells and to see if this natural product may find application in medicine.
\end{abstract}

KEY WORDS: comet assay, DNA damage, in vitro studies, melittin, micronucleus test

Over the past few years, a number of studies were published on the beneficial role of bee venom including radioprotective(1), antimutagenic (2), antiinflammatory (3), antinociceptive (4), and anticancer activities (5). In addition, recent studies reported several effects of bee venom such as induction of apoptosis and necrosis, and effects on proliferation, cytotoxicity, and growth inhibition of different types of cancer cells (6-11).

Bee venom is a very complex mixture of at least 18 active components including peptides, enzymes, and amines, which have a wide variety of properties. The major components of bee venom are melittin, phospholipase $\mathrm{A}_{2}$, apamin, adolapin, histamine, catecholamines, and mast cell degranulating peptide $(12,13)$. Melittin is the main component and the principal toxin in bee venom, and comprises around $50 \%$ of the dry weight of the venom (14, $15)$. This protein is a highly basic polypeptide with molecular weight of $2850 \mathrm{Da}$ and a known amino acid sequence consisting of 26 amino acid residues $(16,17)$. Melittin is mostly hydrophobic, but does have a hydrophilic sequence near the C-terminus (18). It is known that melittin affects erythrocytes, leukocytes, thrombocytes, and many pharmacological systems (19). It is also known to damage the cell membrane enzyme system and that it possesses lytic properties, probably due to its ability to insert itself into phospholipid layers $(15,19)$.

A combination of cytogenetic methods may improve assessment of the cell status after exposure to different types of natural compounds. These methods make it possible to evaluate cytotoxic effects even at the level of primary DNA damage or to establish 
the dynamics of its repair after exposure to cytotoxic and/or genotoxic agents.

The comet assay and micronucleus test are fast and effective tools for assessing the primary toxic effects induced by chemical and physical agents (20-22). The comet assay is a rapid, sensitive, and relatively simple method for detecting DNA damage at the level of individual cell. It combines the simplicity of biochemical techniques for detecting DNA singlestrand breaks, alkali labile sites, and cross-linking, with the single-cell approach typical of cytogenetic assays (23).

With its simple scoring, the micronucleus test has been an attractive cytogenetic tool for assessing exposure to cytotoxic and/or genotoxic agents. Micronucleus test parameters are considered effective biomarkers of processes associated with the aneugenic and clastogenic damage (24).

The aim of this in vitro study was to see the effects of a high concentration of bee venom on the DNA and on the cell. To do this, we exposed human peripheral blood lymphocytes to bee venom from 10 minutes to 24 hours. The concentration of bee venom in the lymphocyte culutes was $100 \mu \mathrm{g} \mathrm{mL}^{-1}$ in all experiments.

\section{MATERIALS AND METHODS}

\section{Blood sampling}

Human blood was obtained from a healthy male donor (26 years of age). The donor had not been exposed to ionising radiation for diagnostic or therapeutic purposes or to known genotoxic chemicals for a year before blood sampling. Venous blood was collected under sterile conditions in heparinised vacutainer tubes (Becton Dickinson, NJ, USA) containing lithium heparin as anticoagulant. After collection, blood was divided into a large number of samples.

\section{Bee venom}

Lyophilised whole bee venom was purchased from Sigma Chemical Co. Just before the beginning of the experiment, bee venom was dissolved in sterile redistilled water at $25{ }^{\circ} \mathrm{C}$, and centrifuged at 12,000 $\mathrm{rpm}$ for $10 \mathrm{~min}$ to remove insoluble materials. The aliquote of bee venom water solution was added to lymphocyte cultures to make the final concentration of $100 \mu \mathrm{g} \mathrm{mL}^{-1}$.

\section{Experimental design}

All experiments were conducted on the same blood sample treated with bee venom in the final concentration of $100 \mu \mathrm{g} \mathrm{mL}^{-1}$ for $10 \mathrm{~min}, 30 \mathrm{~min}$, $1 \mathrm{~h}, 6 \mathrm{~h}$, and $24 \mathrm{~h}$. Whole blood and cell cultures in Euroclone medium were incubated in vitro at $37^{\circ} \mathrm{C}$ in a humified atmosphere with $5.0 \% \mathrm{CO}_{2}$ (Heraeus Heracell 240 incubator, Langenselbold, Germany). After the treatment, all experiments were conducted according to the standard protocols.

\section{Cell viability test}

Cell viability and necrosis were determined by differential staining with acridine orange and ethidium bromide and by fluorescence microscopy (25). Peripheral blood lymphocytes were exposed to whole bee venom over different lengths of time. Lymphocytes were isolated using a modified FicollHistopaque centrifugation method (26). The slides were prepared using $200 \mu \mathrm{L}$ of human peripheral blood lymphocytes and $2 \mu \mathrm{L}$ of stain (acridine orange and ethidium bromide, both diluted in phosphate-buffered saline; PBS). A total of 100 cells per repetition were examined with an Olympus AX-70 microscope, using a $60 \mathrm{x}$ objective and fluorescence filters of $515 \mathrm{~nm}$ to $560 \mathrm{~nm}$. The cells were divided in two categories: a) live cells with a functional membrane, with uniform green staining of the nucleus and $b$ ) necrotic cells with uniform orange staining of the nucleus.

\section{Measurement of lymphocyte DNA damage with the alkaline comet assay}

The comet assay was performed as previously described by Singh et al. $(23,27)$ with minor modifications. Five microlitres of whole blood were carefully re-suspended in $100 \mu \mathrm{L}$ of $0.5 \%$ low melting point (LMP) agarose, layered onto microscope slides that had been pre-coated with $300 \mu \mathrm{L}$ of $0.5 \%$ normal melting point (NMP) agarose. Coverslips were placed on the slides, and the agarose was allowed to solidify for $10 \mathrm{~min}$ on ice. After removal of the coverslips, $100 \mu 1$ of $0.5 \%$ LMP were again spread over the slides, which were then covered with coverslips and kept for another $10 \mathrm{~min}$ on ice. The coverslips were removed and the slides immersed in cold fresh lysing solution $\left(2.5 \mathrm{~mol} \mathrm{~L}^{-1} \mathrm{NaCl}, 100 \mathrm{mmol} \mathrm{L}^{-1} \mathrm{Na}_{2}\right.$ EDTA, $10 \mathrm{mmol} \mathrm{L}^{-1}$ Tris, $10 \%$ DMSO, $1 \%$ Triton X-100, and $1 \%$ laurosylsarcosinate, $\mathrm{pH} 10$ ). To avoid additional DNA damage, these procedures were performed under dim light. Afterwards, the slides were placed for 
$20 \mathrm{~min}$ in a horizontal gel electrophoresis tank filled with cold electrophoresis buffer $\left(1 \mathrm{mmol} \mathrm{L}^{-1} \mathrm{Na}_{2}\right.$ EDTA and $300 \mathrm{mmol} \mathrm{L}^{-1} \mathrm{NaOH}, \mathrm{pH} 13.5$ ) to allow DNA to unwind. Electrophoresis was then performed in the same buffer for $20 \mathrm{~min}$ at $25 \mathrm{~V}$ and $300 \mathrm{~mA}$. Both the unwinding and electrophoresis were performed in an ice bath. After electrophoresis, the slides were neutralised three times for 5 min with $0.4 \mathrm{~mol} \mathrm{~L}^{-1}$ Tris (pH 7.5). The slides were stained with $20 \mu \mathrm{g} \mathrm{mL}^{-1}$ $\mathrm{EtBr}$ (ethidium bromide) just before analysis. Finally, the slides were examined under a Zeiss fluorescence microscope (250x) equipped with a (515 to 560$) \mathrm{nm}$ excitation filter and a $590 \mathrm{~nm}$ barrier filter. Cell images were analysed with a computerised image analysis system Comet Assay II (Perceptive Instruments Ltd., UK). One hundred randomly selected cells were analysed per sample. To quantify DNA damage, the following cometparameters were evaluated: tail length $(\mu \mathrm{m})$, tail intensity ( $\%$ DNA), and tail moment. Tail length (i.e. the length of DNA migration) is directly related to the DNA fragment size and is expressed in micrometers. It was calculated from the centre of the cell. Tail intensity and tail moment were calculated by the computer. For each sample, we also analysed the frequency of long-tailed nuclei (LTN) with the tail length exceeding the $95^{\text {th }}$ percentile of control (28). The analysis did not include the edges and damaged parts of the gel as well as debris, superimposed comets, and comets without distinct head ("clouds", "hedgehogs", or "ghost cells").

\section{Micronucleus test in cultured human lymphocytes}

The micronucleus test was performed following the guidelines described by Fenech and Morley (24) and Fenech et al. (29). Whole blood was added to Euroclone medium (chromosome kit P, Euroclone,
Italy). Human lymphocytes were incubated at $37^{\circ} \mathrm{C}$ for $72 \mathrm{~h}$. Cytocalasin-B was added to arrest cytokinesis at $44 \mathrm{~h}$ after the start of the culture. The final concentration of cytocalasin B in lymphocyte cultures was $3 \mu \mathrm{g} \mathrm{mL}^{-1}$. The cells were then harvested by centrifugation (1000 rpm, $10 \mathrm{~min})$, and the pellet was re-suspended in a hypotonic solution of $0.075 \mathrm{~mol} \mathrm{~L}^{-1} \mathrm{KCI}$. The cells were re-centrifuged and fixed three times in cold methanol:acetic acid (3:1). Slides were prepared by dropping and air-drying, and were stained with $5 \%$ Giemsa (Sigma). One thousand binuclear lymphocytes were analysed to determine the frequency of micronuclei (MNs), their distribution per micronucleated cell, and the presence of nucleoplasmic bridges (NPBs) and nuclear buds (NBs).

\section{Statistical analysis}

For the comet assay, each experimental set contained duplicated slides. The parameters (tail length, tail intensity, and tail moment) measured in the exposed and control groups were evaluated using a Statistica 5.0 package (StatSoft, Tulsa, USA). Each sample was characterised for the extent of DNA damage by considering the mean $\pm \mathrm{SD}$ (standard deviation of the mean), median, and range of the comet parameters. In order to normalise distribution and to equalise the variances, a logarithmic transformation of data was applied. The log-transformed data were then used to make multiple comparisons between the groups by means of ANOVA. Post-hoc analysis of differences was done with the Scheffé test. As for the micronucleus test, the total number and distribution of micronuclei was analysed using the chi-square test. The level of statistical significance was set at $P<0.05$

Table 1 Baseline DNA damage for the comet parameters (tail length, tail intensity, and tail moment) in human peripheral blood

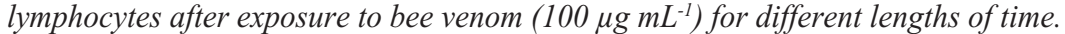

\begin{tabular}{|c|c|c|c|c|c|c|c|c|c|c|c|c|c|}
\hline \multirow{3}{*}{$\begin{array}{c}\text { Exposure } \\
\text { time }\end{array}$} & \multicolumn{12}{|c|}{ Comet parameters } & \multirow{3}{*}{\begin{tabular}{|c|} 
LTN \\
$\%$ \\
\end{tabular}} \\
\hline & \multicolumn{4}{|c|}{ Tail length / $\mu \mathrm{m}$} & \multicolumn{4}{|c|}{ Tail intensity / \% DNA } & \multicolumn{4}{|c|}{ Tail moment } & \\
\hline & Min. & Mean \pm SD & Max. & Median & Min. & Mean \pm SD & Max. & Median & Min. & Mean \pm SD & Max. & Median & \\
\hline $10 \min$ & 10.90 & $12.85 \pm 1.21$ & 16.67 & 12.82 & 0.00 & $1.02 \pm 1.98$ & 15.27 & 0.45 & 0.00 & $0.12 \pm 0.23$ & 1.76 & 0.05 & $10^{*}$ \\
\hline $30 \mathrm{~min}$ & 10.90 & $13.69 \pm 1.31^{*}$ & 17.95 & 13.46 & 0.00 & $0.98 \pm 1.75$ & 11.30 & 0.38 & 0.00 & $0.12 \pm 0.21$ & 1.23 & 0.05 & $27^{*}$ \\
\hline $1 \mathrm{~h}$ & 12.18 & $13.74 \pm 1.28 *$ & 17.95 & 13.46 & 0.00 & $1.15 \pm 1.71$ & 10.80 & 0.40 & 0.00 & $0.14 \pm 0.20$ & 1.32 & 0.05 & $26^{*}$ \\
\hline $6 \mathrm{~h}$ & 12,18 & $15.56 \pm 2.76^{*}$ & 21.15 & 15.38 & 0.00 & $3.73 \pm 4.51^{*}$ & 20.47 & 2.01 & 0.00 & $0.47 \pm 0.57 *$ & 2.62 & 0.27 & $57^{*}$ \\
\hline $24 \mathrm{~h}$ & 13.46 & $23.83 \pm 5.52 *$ & 33.97 & 24.36 & 0.20 & $17.59 \pm 9.35^{*}$ & 40.00 & 18.89 & 0.00 & $2.53 \pm 1.42 *$ & 5.90 & 2.69 & $95^{*}$ \\
\hline Control & 10.90 & $12.68 \pm 0.81$ & 14.10 & 12.82 & 0.00 & $0.87 \pm 1.13$ & 5.68 & 0.45 & 0.00 & $0.10 \pm 0.12$ & 0.59 & 0.05 & 0 \\
\hline
\end{tabular}

* Statistically significant increase in respect to control $(P<0.05)$.

LTN = long-tailed nuclei 

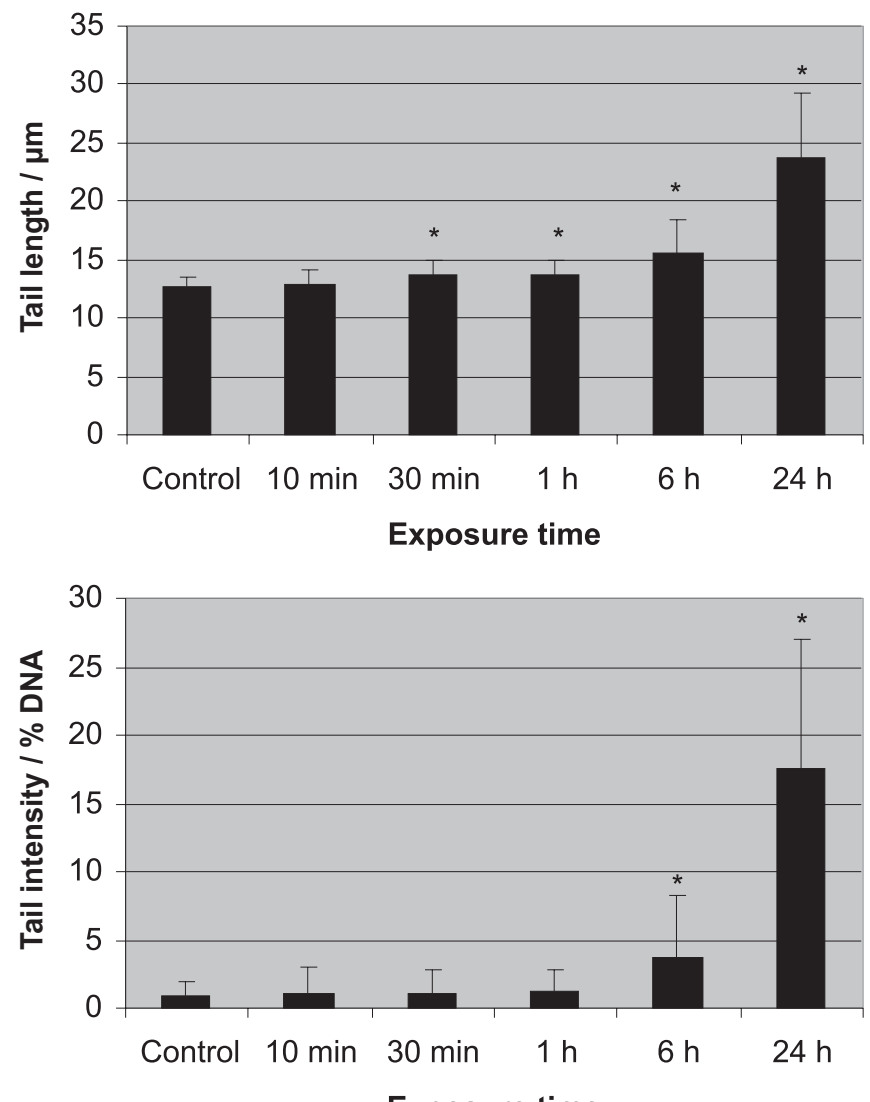

Exposure time

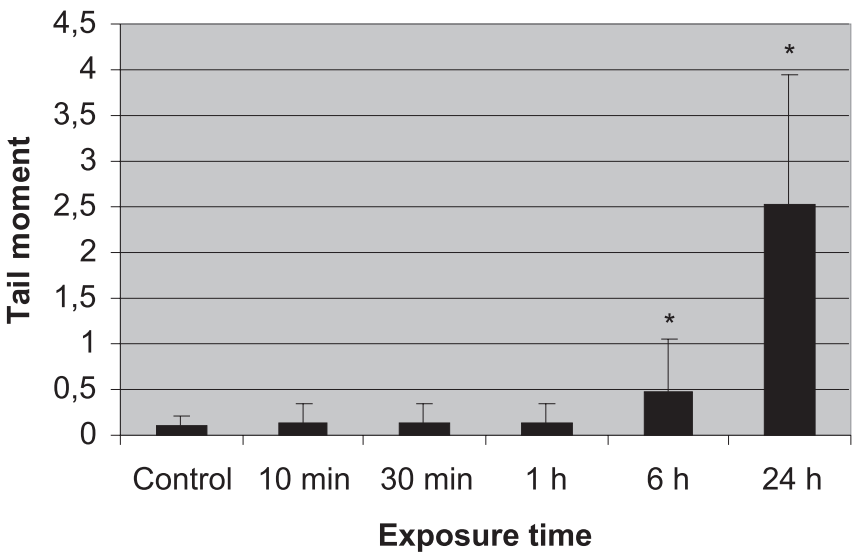

Figure 1 Parameters of the comet assay (tail length, tail intensity and tail moment) expressed as mean values \pm standard deviation measured in unexposed human peripheral blood lymphocytes (control) and those exposed to bee venom

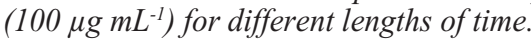

*statistically significant increase in respect to control $(P<0.05)$.

\section{RESULTS}

\section{Cell viability}

The viability of the cells, as determined by acridine orange and ethidium bromide staining, using fluorescence microscopy, was consistently above $79 \%$ in all the exposed samples and above $95 \%$ in control samples. This is considered to be in acceptable range for conducting the comet assay $(30,31)$.

\section{Comet assay}

The mean value $\pm \mathrm{SD}$ of the comet tail lengths was $(12.68 \pm 0.81) \mu \mathrm{m}$ for the control sample. The mean \pm $\mathrm{SD}$ for the bee venom (BV) treated samples ranged from $(12.85 \pm 1.21) \mu \mathrm{m}$ to $(23.83 \pm 5.52) \mu \mathrm{m}$, depending 
on the length of treatment. Mean tail intensity was $(0.87 \pm 1.13) \%$ DNA for the control sample and from $(0.98 \pm 1.25) \%$ DNA to $(17.59 \pm 9.35) \%$ DNA for the treated samples, depending on the length of treatment. Mean comet moment was $(0.10 \pm 0.12)$ for the control sample and from $(0.12 \pm 0.21)$ to $(2.53 \pm 5.90)$ for the treated samples, depending on the length of treatment. All comets were classified according to the threshold level for long-tailed nuclei (LTNs). The cut-off value in this study was $14.10 \mu \mathrm{m}$, and all comets with a greater tail length were considered LTN, and cells categorised as "damaged". The percentage of LTNs ranged from $10 \%$ to $95 \%$, depending on the length of treatment, whereas control samples has no LTNs.

Table 1 shows the basic statistics for the parameters of comet assay for different exposure lengths. According to the one-way ANOVA, tail length significantly deviated from the normal distribution in cells exposed to bee venom for $30 \mathrm{~min}$ and over, whereas tail intensity and tail moment significantly differed from controls in cells exposed for $6 \mathrm{~h}$ and over (Figure 1). The significant differences observed for all three parameters were time dependent.

\section{Micronucleus test}

Table 2 summarises the frequency and distribution of micronuclei, nucleoplasmic bridges, and nuclear buds in the exposed and control groups of cells. The total number of micronuclei observed in binuclear peripheral blood lymphocytes of the exposed samples (ranging from 18 to 22$)$ was significantly $(P<0.05)$ higher than in the control sample (2). The number of nucleoplasmic bridges (ranging from 12 to 16 ) and nuclear buds (ranging from 6 to 18) was also significantly $(P<0.05)$ higher in samples treated with bee venom than in controls, which showed nucleoplasmic bridges or nuclear buds.

\section{DISCUSSION AND CONCLUSION}

The alkaline comet assay and the micronucleus test are the two most widely applicable techniques today for evaluation of cytogenetic alterations in cells exposed to physical and chemical agents.

Comet assay, also known as the single-cell gel electrophoresis, is a powerful tool for measuring DNA damage in eukaryotic cells. This technique has become one of the standards for assessing genome damage, with a variety applications in genotoxicity testing and fundamental research in DNA damage and repair (27). The comet assay detects primary DNA damage, and makes it possible to study the repair kinetics at the level of a single cell (32). There is a variety of possible modifications of the assay which facilitate the detection of single-strand DNA breaks, alkali-labile sites, double-strand DNA breaks, incomplete excision repair sites, and interstrand crosslinks (33). The comet assay can also be used to assess DNA fragmentation associated with cell death or apoptosis $(34,35)$.

In addition to the comet assay, another widely used assay is the micronucleus test which makes it possible to distinguish between clastogenic and aneugenic effects $(24,36)$. Micronuclei are an effective biomarker of diseases and processes associated with DNA damage. The cytokinesis-block micronucleus assay (CBMN) has solved the problem of variation in micronucleus frequency caused by alterations in the proportion of dividing cells which may occur when cells are exposed to genotoxic agents, by restricting the scoring of micronuclei to once-divided cells (31). In addition to measuring cytogenetic damage with the number and distribution of micronuclei, CBMN also detects nucleoplasmic bridges, and nuclear buds. Current evidence suggests that nucleoplasmic bridges derive from dicentric chromosomes in which the centromeres have been pulled to the opposite poles of

Table 2 Total number and distribution of micronuclei, nucleoplasmic bridges, and nuclear buds in human peripheral blood

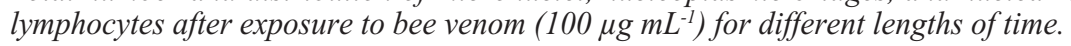

\begin{tabular}{|c|c|c|c|c|c|c|c|c|}
\hline \multirow{2}{*}{$\begin{array}{l}\text { Exposure } \\
\text { time / h }\end{array}$} & \multicolumn{3}{|c|}{$\begin{array}{c}\text { Incidence of } \\
\text { binucleated lymphocytes }\end{array}$} & \multirow{2}{*}{$\begin{array}{l}\text { Total no. } \\
\text { of MNs }\end{array}$} & \multicolumn{2}{|c|}{ Nucleoplasmic bridges } & \multicolumn{2}{|c|}{ Nuclear buds } \\
\hline & Without MNs & $1 \mathrm{MN}$ & $2 \mathrm{MNs}$ & & $1 \mathrm{NPB}$ & 2 NPBs & $1 \mathrm{NB}$ & $2 \mathrm{NBs}$ \\
\hline 1 & 979 & $18 *$ & 3 & $24 *$ & $13 *$ & - & $6^{*}$ & 2 \\
\hline 6 & 974 & $19^{*}$ & $7 *$ & $33 *$ & $16^{*}$ & 1 & $11^{*}$ & 1 \\
\hline 24 & 978 & $22 *$ & - & $22 *$ & $12 *$ & 1 & $18 *$ & 5 \\
\hline Control & 998 & 2 & - & 2 & - & - & - & - \\
\hline
\end{tabular}

$M N=$ micronucleus $; N P B=$ nucleoplasmic bridge $; N B=$ nuclear bud

* Statistically significant increase in respect to control $(P<0.05)$. 
the cell during the anaphase stage, and are therefore indicative of the DNA mis-repair, chromosome rearrangement, or telomere end-fusion. Nuclear buds arise from the elimination of amplified DNA and possibly from the elimination of DNA repair complexes, and can therefore serve as markers of gene amplification and altered gene dosage (29, 38-40).

Our alkaline comet assay showed that bee venom had a great impact on DNA stability, which was indicated by a statistically significant, time-dependent increase in all comet parameters. It was the most obvious for the tail length, which significantly deviated from the normal distribution with exposure length of 30 minutes and higher. In addition, the difference in LTN was statistically significant between the exposed and control samples, regardless of exposure length.

These results are in accordance with our earlier study using bee venom in a concentration range from $5 \mu \mathrm{g} \mathrm{mL}^{-1}$ to $100 \mu \mathrm{g} \mathrm{mL}^{-1}$ over different exposure times. In that study, we observed a statistically significant increase in the tail length and tail moment in human lymphocytes treated with bee venom. These results showed that the extent of DNA damageI was time- and dose- dependent (41). Lee at al. (42) found a similar effect. In their study, an even lower concentration of whole bee venom induced singlestrand DNA breaks in human lymphocytes. The same was observed in another study by Ip et al. (43), where the comet assay also showed that bee venom induced DNA damage.

In addition to the comet parameters, we evaluated the cytogentic effect of bee venom using the micronucleus test. We noticed that all method parameters, the number of micronuclei, nucleoplasmic bridges, and nuclear buds, were significantly higher for all lengths of exposure, and were also timedependent. We noticed that all method parameters, the number of micronuclei, nucleoplasmic bridges, and nuclear buds, were significantly higher for all lengths of exposure and were also time-dependent. This was not the case with the study done by Lee et al. (42); they did notice a slight increase in micronucleus frequency, but their concentrations were much lower than ours. Additionally, in cells exposed for $24 \mathrm{~h}$ we observed the absence of cytoplasm, which can be due to melittin disruption of the cell membrane. Melittin is known to have effects on erythrocytes, leukocytes, thrombocytes, and many pharmacological systems (19). Moreover, as we were isolating the lymphocytes, we noticed that the separation medium (Histopaque) changed colour due to erythrocyte haemolysis.
All of the above effects of bee venom can largely be attributed to melittin, which accounts for over $50 \%$ of its content. This peptide has a highly cytotoxic effect on different types of cells, mostly due to disruption of the cell membrane. Namely, melittin shares its amphipathic properties with a series of peptides that affect the cell membrane bilayer integrity, either by creating defects, disrupting it, or by forming pores (44).

In conclusion, our results indicate that bee venom causes cellular instability. Further research is needed to for us to understand the mechanism of action of bee venom and its components on human cells, and to see if this natural product could find application in medicine.

\section{Acknoweldgements}

This study was supported by the Croatian Ministry of Science, Education and Sports (grant no. 0022-02221482125).

\section{REFERENCES}

1. Varanda EA, Tavares DC. Radioprotection: Mechanism and radioprotective agents including honey bee venom. Venom Anim Toxins 1998;4:5-21.

2. Varanda EA, Monti R, Tavares DC. Inhibitory effect of propolis and bee venom on the mutagenicity of some direct- and indirect-acting mutagens. Teratogen Carcinogen Mutagen 1999;19:403-13.

3. Nam KW, Je KH, Lee JH, Han HJ, Lee HJ, Kang SK, Mar W. Inhibition of COX-2 activity and proinflammatory cytokines (TNF-alpha and IL-1beta) production by water-soluble subfractionated parts from bee (Apis mellifera) venom. Arch Pharm Res 2003;26:383-8.

4. Kim HW, Kwon YB, Ham TW, Roh DH, Yoon SY, Lee HJ, Han HJ, Yang IS, Beitz AJ, Lee JH. Acupoint stimulation using bee venom attenuates formalin-induced pain behavior and spinal cord fos expression in rats. J Vet Med Sci 2003;65:349-55.

5. Orsolic N, Sver L, Verstovsek S, Terzic S, Basic I. Inhibition of mammary carcinoma cell proliferation in vitro and tumor growth in vivo by bee venom. Toxicon 2003;41:861-70.

6. Liu X, Chen D, Xie L, Zhang R.Effect of honey bee venom on proliferation of K1735M2 mouse melanoma cells in-vitro and growth of murine B16 melanomas in-vivo. J Pharm Pharmacol 2002;54:1083-9.

7. Jang M.H, Shin MC, Lim S, Han SM, Park HJ, Shin I. Bee venom induces apoptosis and inhibits expression of cyclooxygenase-2 mRNA in human lung cancer cell line NCI-H1299. J Pharmacol Sci 2003;91:95-104.

8. Yin CS, Lee HJ, Hong SJ, Chung JH, Koh HG. Microarray analysis of gene expression in chondrosarcoma cells treated with bee venom. Toxicon 2005;45:81-91.

9. $\mathrm{Hu} \mathrm{H}$, Chen D, Li Y, Zhang X. Effect of polypeptides in bee venom on growth inhibition and apoptosis induction of the human hepatoma cell line SMMC-7721 in-vitro and Balb/c nude mice in-vivo. J Pharm Pharmacol 2006;58:83-9. 
10. Moon DO, Park SY, Heo MS, Kim KC, Park C, Ko WS. Key regulators in bee venom-induced apoptosis are $\mathrm{Bcl}$ 2 and caspase-3 in human leukemic U937 cells through downregulation of ERK and Akt. Int Immunopharmacol 2006;6:1796-807.

11. Han S, Lee K, Yeo J, Kweon H, Woo S, Lee M, Baek H, Kim S, Park K. Effect of honey bee venom on microglial cells nitric oxide and tumor necrosis factor-alpha production stimulated by LPS. J Ethnopharmacol 2007;111:176-81.

12. Habermann E. Bee and wasp venoms. Science 1972;177:31422.

13. Dotimas EM, Hamid KR, Hider RC, Ragnarsson U.. Isolation and structure analysis of bee venom mast cell degranulating peptide. Biochim Biophys Acta 1987;911:285-93.

14. Neumann W, Habermann E. Characterization of the substances of the bee venom. Naunyn Schmiedebergs Arch Exp Pathol Pharmakol 1954;222:267-87.

15. Vogel H. Incorporation of melittin into phosphatidylcholine bilayers. Study of binding and conformational changes. FEBS Lett 1981;134:37-42.

16. Gauldie J, Hanson JM, Rumjanek FD, Shipolini RA, Vernon CA. The peptide components of bee venom. Eur J Biochem 1976;1:369-76.

17. Gevod VS, Birdi KS. Melittin and the 8-26 fragment. Differences in ionophoric properties as measured by monolayer method. Biophys J 1984;45:1079-83.

18. Habermann E. Chemistry, pharmacology, and toxicology of bee, wasp and hornet venoms. In: Bucherl W, and Buckley EE, editors. Venomous animals and their venoms. Vol. 3. New York (NY): Academic Press; 1971. p. 61-93.

19. Fletcher JE, Jiang MS. Possible mechanisms of action of cobra snake venom cardiotoxins and bee venom melittin. Toxicon 1993;31:669-95.

20. Gajski G, Ravlic S, Capuder Z, Garaj-Vrhovac V. Use of sensitive methods for detection of DNA damage on human lymphocytes exposed to p,p'-DDT: Comet assay and new criteria for scoring micronucleus test. J Environ Sci Health B 2007;42:607-13.

21. Gajski G, Garaj-Vrhovac V. Application of cytogenetic endpoints and comet assay on human lymphocytes treated with atorvastatin in vitro. J Environ Sci Health A Tox Hazard Subst Environ Eng 2008:43:78-85.

22. Gajski G, Garaj-Vrhovac V, Orescanin V. Cytogenetic status and oxidative DNA-damage induced by atorvastatin in human peripheral blood lymphocytes: Standard and Fpg-modified comet assay. Toxicol Appl Pharmacol 2008;231:85-93.

23. Singh NP, McCoy MT, Tice RR, Schneider LL. A simple technique for quantitation of low levels of DNA damage in individual cells. Exp Cell Res 1988;175:184-91.

24. Fenech M, Morley AA. Measurement of micronuclei in lymphocytes. Mutat Res 1985;147:29-36.

25. Duke RC, Cohen JJ. Morphological and biochemical assays of apoptosis. In: Coligan JE, Kruisbeal AM, editors. Current protocols in immunology. New York (NY): John Willey \& Sons; 1992. p. 1-3

26. Singh NP. Microgels for estimation of DNA strand breaks, DNA protein crosslinks and apoptosis. Mutat Res 2000; $455: 111-27$.

27. Collins AR. The comet assay for DNA damage and repair: principles, applications, and limitations. Mol Biotechnol 2004;26:249-61.

28. Betti C, Davini T, Giannessi L, Loprieno N, Barale R. Microgel electrophoresis assay (comet test) and SCE analysis in human lymphocytes from 100 normal subjects. Mutat Res 1994:307:323-33.

29. Fenech M, Chang WP, Kirsch-Volders M, Holland N, Bonassi S, Zeiger E. HUMN project: detailed description of scoring criteria for the cytokinesis-block micronucleus assay using isolated human lymphocyte cultures. Mutat Res 2003;534:65-75.

30. Henderson L, Wolfreys A, Fedyk J, Bourner C, Windebank $\mathrm{S}$. The ability of the Comet assay to discriminate between genotoxins and cytotoxins. Mutagenesis 1998;13:89-94.

31. Tice RR, Agurell E, Anderson D, Burlinson B, Hartmann A, Kobayashi H, Miyamae Y, Rojas E, Ryu JC, Sasaki YF. Single cell gel/comet assay: guidelines for in vitro and in vivo genetic toxicology testing. Environ Mol Mutagen 2000;35:206-16.

32. Hellman B, Vaghef H, Boström B. The concepts of tail moment and tail inertia in the single cell gel electrophoresis assay. Mutat Res 1995;336:123-31.

33. Kumaravel TS, Vilhar B, Faux SP, Jha AN. Comet Assay measurements: a perspective. Cell Biol Toxicol 2009;25:5364.

34. Olive PL. DNA damage and repair in individual cells: applications of the comet assay in radiobiology. Int J Radiat Biol 1999;75:395-405.

35. Piperakis SM, Visvardis EE, Tassiou AM. Comet assay for nuclear DNA damage. Methods Enzymol 1999;300:184-94.

36. Kirsch-Volders M, Sofuni T, Aardema M, Albertini S, Eastmond D, Fenech M, Ishidate MJr, Kirchner S, Lorge E, Morita T, Norppa H, Surralles J, Vanhauwaert A, Wakata A. Report from the in vitro micronucleus assay working group. Mutat Res 2003;540:153-63.

37. Fenech $\mathrm{M}$. The in vitro micronucleus technique. Mutat Res 2000;455:81-95.

38. Fenech M. Cytokinesis-block micronucleus assay evolves into a "cytome" assay of chromosomal instability, mitotic dysfunction and cell death. Mutat Res 2006;600:58-66.

39. Garaj-Vrhovac V, Gajski G, Ravlić S. Efficacy of HUMN criteria for scoring the micronucleus assay in human lymphocytes exposed to a low concentration of p,p'-DDT. Braz J Med Biol Res 2008;41:473-6.

40. Garaj-Vrhovac V, Đurinec M, Kojpar N, Oreščanin V. A survey on the cytogenetic status of the Croatian general population by use of the cytokinesis-block micronucleus assay. Mutat Res 2008;649:91-100.

41. Gajski G, Garaj-Vrhovac V. Genotoxic potential of bee venom (Apis mellifera) on human peripheral blood lymphocytes in vitro using single cell gel electrophoresis assay. J Environ Sci Health A Tox Hazard Subst Environ Eng 2008;43:1279-87.

42. Lee YJ, Kang SJ, Kim BM, Kim YJ, Woo HD, Chung HW. Cytotoxicity of honeybee (Apis mellifera) venom in normal human lymphocytes and HL-60 cells. Chem Biol Interact 2007;169:189-97.

43. Ip SW, Liao SS, Lin SY, Lin JP, Yang JS, Lin ML, Chen GW, Lu HF, Lin MW, Han SM, Chung JG. The role of mitochondria in bee venom-induced apoptosis in human breast cancer MCF7 cells. In Vivo 2008;22:237-45.

44. Stuhlmeier KM. Apis mellifera venom and melittin block neither NF-kappa B-p50-DNA interactions nor the activation of NF-kappa B, instead they activate the transcription of proinflammatory genes and the release of reactive oxygen intermediates. J Immunol 2007;179:655-64. 
Sažetak

\section{PROCJENA CITOGENETIČKOG STATUSA U LJUDSKIM LIMFOCITIMA NAKON IZLOŽENOSTI VISOKIM KONCENTRACIJAMA PČELINJEG OTROVA U UVJETIMA IN VITRO}

Cilj ovog istraživanja je procjena staničnog statusa ljudskih limfocita periferne krvi nakon tretmana visokom koncentracijom pčelinjeg otrova u in vitro uvjetima primjenom alkalnog kometnog testa i mikronukleusnog testa. Limfociti su bili izloženi pčelinjem otrovu u koncentraciji od $100 \mu \mathrm{g} \mathrm{mL^{-1 }} \mathrm{u}$ različitom vremenu (od 10 min do 24 h). Rezultati kometnog testa upućuju na oštećenje molekule DNA povećanjem parametara kometnog testa (dužina repa, intenzitet repa i repni moment) te prisutnost limfocita s visokom učestalosti kometa s dugim repovima (LTN). U tim stanicama učestalost LTN premašuje $95 \%$ ukupne raspodjele vrijednosti LTN dobivene za sve stanice kontrolnog uzorka. Parametri mikronukleusnog testa (broj mikronukleusa, nukleoplazmatski mostovi i nuklearni pupovi) također pokazuju značajan porast u odnosu na odgovarajući kontrolni uzorak $(\mathrm{P}<0,05)$. Rezultati dobiveni ovim tehnikama upućuju na to da pčelinji otrov u visokoj koncentraciji uzrokuje staničnu nestabilnost te na potrebu daljnjih istraživanja mehanizama djelovanja pčelinjeg otrova i njegovih sastavnica na ljudske stanice u svrhu primjene prirodnih spojeva posebice u medicinskoj praksi.

KLJUČNE RIJEČI: in vitro studija, kometni test, melitin, mikronukleusni test, oštećenje DNA

\section{CORRESPONDING AUTHOR:}

Verica Garaj-Vrhovac, Ph.D.

Institute for Medical Research and Occupational Health P.O. Box 291, HR-10001 Zagreb, Croatia

E-mail:vgaraj@imi.hr 